\title{
How Can International Students Overcome Their Biggest Obstacle In An American University?
}

Waneen Aden White, George Fox University, USA Caleb Rosado, Warner Pacific College, USA

\begin{abstract}
This paper focuses on an interdisciplinary project using an innovative teaching methodology developed to generate substantive interaction between international students and mainstream students on American campuses. The process was created after asking international students from a variety of countries the question, "What is the biggest obstacle you have in learning English here at our university in America?" The response of these students was that despite their best efforts, they could not seem to connect with their American peers on campus. The international students found it difficult to interact with American students on anything other than a superficial conversational level; and as a result, they tended to feel invisible on campus.

A project was designed to bring about greater interaction and cultural awareness by bringing international students together with native speakers in stimulating and authentic conversations. The project was a success for both mainstream American students and international students by creating a space of equal status between the two student groups; this lowered the social, cultural, and linguistic barriers that were normally present. This paper shows how this was done.
\end{abstract}

Keywords: International Students; Cultural Awareness; Linguistic Barriers; Campus Invisibility; Cultural Discontinuities; Intercultural Communication; IEPs; Cross-Disciplinary

\section{INTRODUCTION}

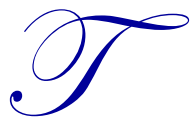

he focus of this project was to define obstacles that international students face at the college level in the United States and to discover innovative teaching methods to overcome them. The inception of the project emerged from asking international students, from a variety of countries who had attained an Early Intermediate English proficiency, to respond to the question, "What is the biggest obstacle in learning English here at our university in America?" The response of these students was unanimous - despite their best efforts, they could not seem to connect with their American peers on campus (Rude, 2009). The international students found it difficult to interact with American students on anything other than a superficial conversational level.

The result was that the international students could not really overcome this "contact barrier" (Mallett \& Wilson, 2009) in order to practice their English with native speakers or even begin to feel part of the campus environment. These students, from largely collectivist cultures, were very aware of sensing themselves as separate from the campus collective group of students (Heggins \& Jackson, 2003).

They wanted to try and connect with their counterparts in the US and had left their home countries to study in the US. However, they still found themselves studying and socializing with groups from their home country or, at best, English Language Learners from other countries. They needed to discuss topics that were genuinely relevant to both Americans and the international students learning English. The international students needed to feel a part of both the academic and social community in the American university; they needed to stop feeling invisible. 


\section{Cultural Discontinuities}

International students have gradually been increasing in numbers on university campuses across America. Most are from countries with largely traditional cultures, with the largest single group being from China; this Chinese population alone accounted for 28\% of international students in the 1999-2000 school year (Yan \& Berliner, 2007). Research by Hofstede, Hofstede, and Minkov (2010), on the dimensions of culture, sheds light on multiple aspects of the cultural dynamics found in most of the countries of the international students that come to study at US universities. Among these are uncertainty avoidance, long-term orientation, cultural distance, power distance, indulgence vs. restraint, individualism, and silent learner versus active learner.

Uncertainty avoidance is high in the Pan-Asian countries as well as in many traditional cultures, which means that there is generally a low tolerance for risk-taking and many societal rules that attempt to control all outcomes and results (Hofstede, 2009). The United States is ranked at 46 - a low uncertainty avoidance value, which means there is a greater degree of comfort in unstructured situations that are "novel, unknown, surprising, [or] different from the usual" (Hofstede, 2009). Another obstacle to communication was the cultural dimension called long-term orientation which values perseverance, filial piety, social obligations, and protecting one's "face" (Hofstede, 2009). China scores highest in this dimension at 118, while the United States scores low at 29 (para. 1). Overall, the United States and China often tend to fall at each end of a continuum of cultural values, leading to a sense of cultural distance (Yan \& Berliner, 2009).

\section{Cultural Dimensions}

In spite of high test scores and a desire to excel, many international students entering the American educational system seemed quite unprepared for the different cultural styles of both the administration, classroom teachers, and American students. The authority of the teachers in their home countries usually involved a greater power distance unlike that found in American classrooms. "Power distance" is the extent to which people having less power in a given society are content with such a status (Hofstede, 2009). Therefore, international students generally had little to no experience participating in American-style classroom discussions; students here freely stated their opinions even without evidence to support their arguments, in a free interchange of ideas between students and teachers on the topic at hand. International students, in contrast, are likely to have learned a certain classroom decorum that involves saving face, respecting the hierarchical position of the teacher above the students, and a receptive - rather than active - engagement; an example of "indulgence vs. restraint." When the language difficulty was added to their cultural distance issues, it is clear that initiating cross-cultural connections was challenging and where few supports were available. According to Yan and Berliner (2007), one Chinese interviewee stated that this "psychological trade-off of the academic autonomy and freedom is the constant insecurity and enormous pressure" (p. 952). The cultural value dimension under discussion is individualism, from which stem the values of freedom and choice.

An additional cultural value seemed to present challenges in the American university classroom (Yan \& Berliner, 2007), which was identified as the "silent learner versus active learner" style preference (p. 953). The result was that the students may appear to not want to participate and generally cannot voice their distress due to cultural aspects of the home culture (Yan \& Berliner, 2009, p. 940). The factor that was the greatest influence, operationally for all the students in a study of academic stressors in Chinese international students, was sociocultural (Lui, 2001, p. 165). International students from other countries seemed to share degrees of this same intercultural dynamic, since these elements were on a continuum of societal norms at the other end of the spectrum from the American students.

\section{PROJECT INCEPTION}

At the time of this research project, one of the authors of this paper was teaching at an English Language Institute at a university in the Northeast. Most of the students in the ELI classes were Asians - primarily from China - although Japanese, Korean, Middle Eastern, Latin American, and African students were also represented in this project. One day after class, while conversing with international students out in the campus center, the researcher, who had come to know them over time, asked, "What is the greatest obstacle you have in learning English here in 
our American university?" After first assuring the researcher that everything was fine, the students eventually shared their frustration that they were not able to connect with the mainstream American students on campus and have meaningful conversations that would move beyond a forced hello, how are you, where are you from? After spending many months living on campus, none of the international students had experienced a real conversation with an American student.

Seeking to come up with a plausible solution to their experience, the professor noticed - at that very moment - a young woman approaching the auditorium doors where they were standing and said, "Excuse me. Do you have a moment? These are some of my international students and they are having difficulty creating conversations with our mainstream students, and I was wondering if you would be willing to spend some time with them in conversation?" "Gladly," Nancy said, and she began to converse with the students with whom she had never connected in the past. The international students responded well. A few days after this initial conversation, Nancy decided she wanted to communicate more with international students. She went to the ELI office to volunteer to be a conversation partner for international students and she was hired.

\section{Research Question}

In light of these socio-cultural dynamics, the following research question was developed: "How can marginalized groups, such as international students in this project, be regarded as important to the whole campus, and invited to communicate their voice and perspective on the college campus?"

\section{COLLABORATIVE PROJECT}

It was important that the professor facilitate the students' first encounter with American college students. Due to cultural differences, many misunderstandings and misinterpretations could arise before any deeper-level communication could be established. In addition, the teacher felt that there needed to be a focus on having in-depth conversations that would build connections beyond the surface niceties. The professor also realized that she needed to work directly with a professor in the university to see if the two could come up with a project that the two groups of students could do together, where their differences would be seen as a positive.

\section{Cross-Disciplinary Interviews}

The way to bring the international students into the group was to respect their status as experts in their firsthand knowledge and experiences in their home countries. The professor approached a colleague in the Sociology Department whose American students at the same university were studying marriage and family patterns around the world. As part of their required course of study, small groups of American students would choose one chapter from their textbook and design questions for the international students. The small group came to the ELI class to treat the internationals students as primary sources and as a focus group for discovering what the sociological norms were in their respective countries. Some sociology topics that engendered much discussion were courting practices, marriage customs, views on love and marriage, arranged marriages, divorce, gender roles, education, child rearing practices, and care of the elderly. For the first time, American students actually spoke to peers from around the world who, for example, expected to have their spouse chosen for them in an arranged marriage, as their parents and previous generations had done. Rather than seeing this as unthinkable in the American psyche, the American students asked the international students to explain in what ways they valued this custom. After listening carefully, the American students were asked to explain how the process of choosing a spouse might work here. An enlightening moment occurred when an American student explained that her friends or family might introduce a person who eventually becomes a spouse - and the international student commented that this process seemed similar to the arranged marriage where family brings two young people together. In that moment, on both sides, judgment and stereotypes were suspended and a realization was made that humans are connected in more ways than it appeared at first.

Subsequent conversations followed with American students explaining their nuclear families while international students explained how an extended family did not seem crowded, how it felt to be in a family with more than one wife, how it felt to be in a family that would never divorce, or whose family would never put an elderly grandparent in a nursing home. Most of the time, only one hour was scheduled for the project, but, 
voluntarily, the session would normally last for three hours with no break and then continue on as they all went to lunch together. If there arose culture shock, a miscommunication, or cultural divide during the discussion, a multiperspective view was initiated. This interaction was broadening the comprehension and connectedness of both groups through equal status contact (Allport, 1954; Pettigrew, 1998).

\section{Assessment and Results}

In the ELI classroom, the students were assessed by memoing their words to find themes that arose in the discussions. The students completed journal reflections and one-minute write-ups to capture the essence of their thoughts after a session. Their confidence in the skills of listening and speaking, often their two weakest English skills, began to improve dramatically as they spoke with native English speakers. Formal assessment was through a paper they submitted on "A Cultural Analysis." An unexpected result of this project was that the writing skills of fluency and syntax improved as a result of the discussions. It appears that fluency and authentic syntax practice transferred across productive and receptive skills. This is an area for further research.

On the part of the sociology students, their professor asked each group to create a PowerPoint presentation on a comparative analysis of the sociological concepts from their session with the international students. A highlight for the international students was when their sociology partners invited them to attend the presentation that included their input. Of great interest to the researcher was to see reserved and quiet international students, who had not yet graduated out of the English Language Institute, respond in a large class to follow-up questions by sociology students. Suddenly the international students were speaking up in an American classroom of $40+$ students because the American students were authentically interested in hearing what they had to say.

\section{Voices of the International Students}

I was surprised by the Chinese customs about marriage because they have almost same custom as we have. But I was surprise when some American students said some different custom and marriage system. For example they don't have any different about men and women in the society. They believe that men and women are equal and they should have same rights. I am totally agreed with their custom and I appreciate this. But I feel that they [USA] have more respects towards women. I also like that they also give respect those children who have single mother. Even we also give respect to single mother or father but if they have baby after marriage, because in our society we will not accept any single mother or father except he or she adopt child.

Some students came to our class to survey about families and their marriage system. They were sociology students. They have some interesting and controversial questions about marriage system and family customs. This time we have questions about children, birth control pills and also who play important role in the marriage.

I was not surprised by the Chinese customs and marriage system. But I was surprise when some Indian said some different custom and marriage system. For example my friend said that 'he went to girl's house and he talked with her parents about their relationship', because this is not common system or custom. The common custom is arranging marriage. Most of the family preferred arranged marriage and even if they allow love marriages, they have to talk with their parents that he or she like someone and he or she wants to marry someone. Then their parents will check that he or she is right for them children.

After listing all the answer from all students I want to conclude that each and every society has their own customs and nobody is perfect in this world. So each and every society have some bad believes or tradition but we can learn good things from other culture like give respects and give same rights to men and women. Now everywhere people are becoming more modern but they should follow their own tradition also.

\section{The Project Expands}

The second writer of this paper, a sociologist who, at the time of this project, was teaching at a nearby state university, was invited to join the cross-cultural project along with his students. He was interested in this innovative approach since he had experienced being a foreign student himself as a child when he came from Puerto Rico not 
knowing any English. There was no program for international students at his university, yet he had spoken multiple times as a guest speaker on Ethnic and Cultural Relations to the international students at the ELI program.

Over a period of one year, several students from the neighboring state university in the Northeast came to engage the ELI students in similar cross-cultural conversations. Most of them were sociology and education majors who went to their first session without knowing what to expect, or even if the international students could understand them. Several of these small groups were so engaged that they volunteered their own time to visit more than once and take other classmates to experience what they had with the international students. In many ways, this method provided a closer connection than they might have had if they had visited the home counties of the students as tourists and had tried to connect with the locals.

This second wave of sociology students came prepared with a list of two questions that each student had to ask the international students. Very quickly the formal questions were dropped as the camaraderie between the two groups of students emerged and the barriers of cultural distance disappeared in the ensuing and developing friendship. Before long, the conversation became one of friends talking with each other. The American students quickly began to regard the international students as just another group of students to connect with. For the international students, the excitement of forming friendships with American students enabled them to focus on the discussion at hand and forget the fact that they were normally nervous when conversing in English (Krashen, 1982). The fear of talking in English disappeared and now they were just students talking with fellow students. Friendships developed, the conversation level heightened, laughter broke out often, and they reported meaningful interaction.

\section{Voices of the American Students}

Man, I never realized how easy it was to talk with these Asian students. If they had been on our campus, I would have ignored them, but this project brought us together and I began to realize just how much we have in common. I will definitely do it again.

In one of our conversations, the topic of violence in the United States came up. I told them that being that I am a criminal justice major and desire to be a police officer, I had a gun. Their eyes just popped out of their heads. They had never known a person to own a gun. The next time I came, I had my holstered service revolver and it generated some interesting discussions with viewpoints I had never considered. This is my third time doing this project and I really enjoy it.

Being a Puerto Rican female and a minority student on campus, I was able to identify with their hesitancy of engaging in conversations with white students on campus, since I have had the same difficulty; but here we were students of color sharing similar experiences. I am definitely doing this again.

As a double sociology and education major, my eyes were opened to the way my future students in the classroom might see the world really differently. I loved this assignment so much that I went several times to their ELI classroom. Every time I learned new things and met some great friends. We met outside the classroom, too, and went to the shore when we American students found out they didn't have cars.

As a Korean-American, I was bilingual but considered myself really American. I have only lived in America my whole life. When I met the international students, I saw some Koreans and I spoke to them in their language. Everyone else became silent for a moment. I saw their shock and gratitude. I felt connected to them as well as the other students in the classroom. By meeting these students from all over the world-including Korea-it helped me see my identity and connection to the whole wider world.

\section{Further Developments}

The outcome of these sessions often created the platform for interracial and interethnic friendships to form since "understanding cross-race friendship formation requires greater attention to the social construction and performance of similarity and difference" (Rude, 2009). Because of the repeated, deep level interaction between the two groups of students, the American and international students voluntarily wanted the friendship to continue 
outside the formal classroom setting. On more than one occasion, the two groups of students went out and socialized at a bar and a restaurant together, and even partied together. A latent outcome of this project was that one American student, a Korean, developed a romantic relationship with one of the international students, another Korean something that the two professors did not see coming.

\section{CONCLUSION}

The fact that the international students represent valuable primary sources for university students in various majors is a largely untapped human resource across college campuses. Beyond what they can do for academia as representatives of world cultures and languages, the interaction of the two groups uncovers the basis for intercultural communication and a global worldview that makes operational the written document of diversity goals for a university (Rosado, 1999). The researchers and professors came to understand that just having different isolated groups occupy the same buildings at a university does not mean cultural awareness, diversity, or an inclusive climate for all students has been attained. When everyone truly connects, respect is gained for others' perspectives. They genuinely value and seek their presence in their lives and they have the foundation of what it means to be "multicultural."

\section{AUTHOR INFORMATION}

Waneen Aden White is an Assistant Professor of Education at George Fox University. She has taught languages to pre-kindergarten through university level students in the US and overseas. Her areas of expertise are: Intercultural Rhetoric and Advanced Biliteracy; Second Language Acquisition; and Diverse Student Populations (K-16). Her current focus is on researching intercultural engagement the Teacher Education program. Her MA in Education is from the University of Connecticut at Storrs. She is completing a $\mathrm{PhD}$ in Education-ESOL/Bilingual at Northcentral University. E-mail: wwhite@georgefox.edu

Dr. Caleb Rosado is a Professor of Urban Studies at Warner Pacific College in Portland, OR, and Director of the Urban Studies Program. He holds a doctorate in sociology from Northwestern University. He has taught in diverse academic settings in the United States, the UK, and in Latin America. Dr. Rosado has also been a human systems consultant since 1978. He has worked on issues of human relations and human systems change with government agencies, universities, K-12 school districts, corporations, churches, and community organizations. He has written three books and numerous professional articles. His latest publication and his current area of research focus is in quantum physics and urban transformation. Many of his published articles can be found in his website: www.rosado.net. E-mail: calebrosado@earthlink.net (Corresponding author)

\section{REFERENCES}

1. $\quad$ Allport, C. W. (1954). The nature of prejudice. Addison-Wesley.

2. Heggins, W., III, \& Jackson, J. (2003). Understanding the collegiate experience for Asian international students at a Midwestern research university. College Student Journal, 37(3), 379. Retrieved December 23, 2010 from Education Research Complete database.

3. Hofstede, G. (2009). Cultural dimensions: China. Retrieved from http://www.geert-hofstede.com/ hofstede_china.shtml

4. Hofstede, G., Hofstede, G. J., \& Minkov, M. (2010). Cultures and organizations: Software for the mind. New York: McGraw-Hill Professional.

5. $\quad$ Krashen, S. D. (1982). Principles and practice in second language acquisition. Oxford: New York: Pergamon.

6. Liu, J. (2001). Asian students' classroom communication patterns in U.S. universities: An emic perspective. Westport, CT: Greenwood Press. LC Call Number: PE1130.A2 -- L58 2001eb.

7. Mallett, R. K., \& Wilson, T. D. (2009). Report: Increasing positive intergroup contact. Journal of Experimental Social Psychology, 46382-387. doi:10.1016/j.jesp.2009.11.006

8. Pettigrew, T. F. (1998). Intergroup contact theory. Annual Review of Psychology, 49, pp. 65-85.

9. Rosado, C. (1999). The multiple futures of racism - Beyond the myth of race through a new paradigm for resolution in the third millennium. Futures Research Quarterly, 15(1), 29-62. 
10. Rude, J. (2008). Putting interracial friendship formation into context. Conference Papers -- American Sociological Association (2008 Annual Meeting 2008): 1. Supplemental Index, EBSCOhost

11. U.S. Census Bureau. (2007). Asian American population estimates. Retrieved from http://factfinder.census.gov/

12. Yan, K., \& Berliner, D. (2009). Chinese international students' academic stressors in the United States. College Student Journal, A43(4), 939-960. Retrieved December 12, 2010 from ProQuest Psychology Journals. (Document ID: 1963115231). 
NOTES 